\title{
Revisiting Biodiversity of Crop Genepools
}

\author{
Commentary \\ Volume 2 Issue 1- 2021

\begin{abstract}
Author Details
Andrés J Cortés*

${ }^{1}$ Corporación Colombiana de Investigación Agropecuaria AGROSAVIA, Colombia
\end{abstract} \\ ${ }^{2}$ Departamento de Ciencias Forestales, Universidad Nacional de Colombia, Colombia \\ *Corresponding author \\ Andrés J Cortés, Corporación Colombiana de Investigación Agropecuaria AGROSAVIA, C.I. La Selva, Km 7 vía Rionegro - Las \\ Palmas, Rionegro, Colombia; Universidad Nacional de Colombia - Sede Medellín, Facultad de Ciencias Agrarias - Departamen-
} to de Ciencias Forestales, Medellín, Colombia

Article History

Received: April 29, 2021 Accepted: May 17, 2021 Published: May 19, 2021

\section{Commentary}

Crop diversity has typically served as a source of novel variants for breeding programs, focusing on yield, quality and nutrition [1]. More recently, it has also assisted addressing basic questions in the field of genetics such as the repeatability of the domestication process [2-4], and the nature of the migration-selection balance in the face of mutation [5-8] and recombination rate variation [9]. Meanwhile, going beyond crop diversity and exploring crop wild relatives is equally promising, specially in the face of adaptation to current climate change [10]. Wild accessions offer an expanded genepool in terms of phenotypic innovation [11] and genetic diversity [12]. For instance, the wild is likely to exhibit pre-adapted variants advantageous to polygenic adaptation [13], such as drought [14-18] and heat [19,20] tolerance. However, merging crop and wild genepools remains challenging from a technical point of view due to phenological and genetic incompatibilities, sometimes bridged via recurrent backcrossing schemes, not to mention the adoption gaps when handling wild materials and early landraces with the potential to serve as novel crops [21]. Hence, leveraging novel approaches [10,19,22] are urgently required to better couple agro- and bio-diversity, both in current hotspots as well as in evolutionary cradles [23]. Of particular interest are the tropical regions [24,25], which not only maintain unparsed diversity [26] but are also the most vulnerable in terms of climate change [27] and crops' market volatility.

International Journal on Agriculture Research and Environmental Sciences (IJARES) is a nascent journal that is presently launching its second issue, and that has the potential to lead a trans-disciplinary inclusive discussion aiming to promote integrative perspectives for harnessing crop wild diversity. The success of any trans-disciplinary effort is conditioned to a bidirectional dialogue among heterogeneous forums. As part of this interaction, my colleagues and I are currently pushing forward a couple of Special Issues focused on biodiversity of crop genepools, that can certainly complement and promote IJARES's scope from other arenas.

The first one, Genes' "Evolutionary Genetics of Plant Crop-Wild Complexes: From Fundamental to Applied Research" (https://www. mdpi.com/journal/genes/special_issues/Plant_Crop_Wild), aims to summarize basic and applied approaches on the evolutionary genetics of plant crop-wild complexes in order to identify current paradigms, methods, and caveats that are widely being used or currently being developed to study crop-wild complexes. It envisions bringing together the hottest topics addressed when investigating genetics and adaptation of crops, their wild relatives, and their abiotic and biotic interactions, by encouraging works in the diverse areas of evolutionary genetics of crop wild relatives, genetic and genomic consequences of domestication, role of crop-wild gene flow during domestication and adaptation, evolutionary genetics of undomesticated plants and trees with bio-economic potential, and wild relatives in the improvement of crops and trees.

The second one, Agronomy's "Omics Approaches for Crop Improvement" (https://www.mdpi.com/journal/agronomy/special_ issues/crop_omics_genetic), envisions offering updated views on multidimensional large-scale omics-based approaches with the potential to be applied at crop-wild systems that are still in their infancy. Specifically, we encourage studies that explore the uses of the omics paradigm, and their integration through trans-disciplinary bioinformatics, as tools to improve qualitative and quantitative traits in crop species. This Special Issue configures itself as a cohesive effort to combine contrasting omic studies (i.e. genomics, transcriptomics, proteomics, metabolomics, phenomics, and enviromics) within common omnigenic pathways and cellular networks of crop systems. Ultimately, this integration will allow pivoting direct and indirect genetic-assisted approaches to enhance agronomical important traits such as yield, resistance and nutritional value. 
Major research avenues persist given the growing human population and severe climate change[28]. The previous compilations do not aim to be exhaustive, but rather encourage a trans-disciplinary conversation around conservation and utilization of crop-wild gene pools biodiversity. IJARES may certainly contribute to this dialogue, together with a consolidated much-needed open-source network of data sharing $[29,30]$.

\section{Acknowledgements}

I am very much grateful with IJARES's Editorial Board and Sandra Ellison for the invitation to contribute a commentary to the second issue of the International Journal on Agriculture Research and Environmental Sciences, as well as with Gene's and Agronomy's editors for planning highly timing Special Issues concerning biodiversity of crop genepools and omics approaches.

\section{References}

1. Wu X, A S M Faridul Islam, Naransa Limpot, Lucas Mackasmiel, Jerzy Mierzwa, et al. (2020) Genome Wide SNP Identification and Association Mapping for Seed Mineral Concentration in Mung Bean (Vigna radiata L). Front Genet 11:656.

2. Schmutz J, Phillip E McClean, Sujan Mamidi, G Albert Wu, Steven B Cannon, et al. (2014) A reference genome for common bean and genome wide analysis of dual domestications. Nat Genet 46(7): 707713.

3. Cortés AJ, Paola Skeen, Matthew W Blair, María I Chacón-Sánchez (2018) Does the genomic landscape of species divergence in Phaseolus beans coerce parallel signatures of adaptation and domestication? Front Plant Sci 9: 1816.

4. Cortés AJ (2013) On the Origin of the Common Bean (Phaseolus vulgaris L). American Journal of Plant Sciences 4(10): 1998-2000.

5. Blair MW, Andrés J Cortés, R Varma Penmetsa, Andrew Farmer, Noelia Carrasquilla-Garcia, et al. (2013) A high throughput SNP marker system for parental polymorphism screening, and diversity analysis in common bean (Phaseolus vulgaris L). Theor Appl Genet 126(2): 535-548.

6. Galeano $\mathrm{CH}$, Andrés J Cortés, Andrea C Fernández, Álvaro Soler, Natalia Franco-Herrera, et al. (2012) Gene-Based Single Nucleotide Polymorphism Markers for Genetic and Association Mapping in Common Bean. BMC Genetics 13(1): 48.

7. Kelleher CT, Jennifer Wilkin, Jun Zhuang, Andrés Javier Cortés, Álvaro Luis Pérez Quintero, et al. (2012) SNP discovery gene diversity, and linkage disequilibrium in wild populations of Populus tremuloides. Tree Genetics \& Genomes 8(4): 821-829.

8. Cortés A J, M C Chavarro, M W Blair (2011) SNP marker diversity in common bean (Phaseolus vulgaris L). Theor Appl Genet 123(5): 827845.

9. Blair MW, Andrés J Cortés, Andrew D Farmer, Wei Huang, Daniel Ambachew, et al. (2018) Uneven recombination rate and linkage disequilibrium across a reference SNP map for common bean (Phaseolus vulgaris L). PLoS One 13(3): e0189597.

10. Cortés A J, M Restrepo Montoya, L E Bedoya Canas (2020) Modern Strategies to Assess and Breed Forest Tree Adaptation to Changing Climate. Front Plant Sci 11: 583323.

11. Cortés A J, Fredy A Monserrate, Julián Ramírez-Villegas, Santiago Madriñán, Matthew W Blair (2013) Drought Tolerance in Wild Plant Populations: the Case of Common Beans (Phaseolus vulgaris L.). Plos One 8(5): e62898.

12. Blair M W, A Soler, A J Cortés (2012) Diversification and Population Structure in Common Beans (Phaseolus vulgaris L) Plos One 7(11): e49488.
13. Arenas S (2021) Evaluating the accuracy of genomic prediction for the management and conservation of relictual natural tree populations. Tree Genetics \& Genomes 17(12).

14. Buitrago Bitar MA, Andrés J Cortés, Felipe López-Hernández, Jorge M Londoño-Caicedo, Jaime E Muñoz-Florez, et al. (2021) Allelic Diversity at Abiotic Stress Responsive Genes in Relationship to Ecological Drought Indices for Cultivated Tepary Bean Phaseolus acutifolius A Gray and Its Wild Relatives. Genes 12(4): 556.

15. Cortés AJ, M W Blair (2018) Genotyping by Sequencing and Genome - Environment Associations in Wild Common Bean Predict Widespread Divergent Adaptation to Drought. Front Plant Sci 9: 128.

16. Blair MW, A J Cortés, D This (2016) Identification of an ERECTA gene and its drought adaptation associations with wild and cultivated common bean. Plant Science 242: 250-259.

17. Cortés AJ, M Carolina Chavarro, Santiago Madriñán, Dominique This, Matthew W Blair (2012) Molecular ecology and selection in the drought-related Asr gene polymorphisms in wild and cultivated common bean (Phaseolus vulgaris L). BMC Genet 13: 58 .

18. Cortés AJ, Dominique This, Carolina Chavarro, Santiago Madriñán, Matthew W Blair (2012) Nucleotide diversity patterns at the droughtrelated DREB2 encoding genes in wild and cultivated common bean (Phaseolus vulgaris L). Theor Appl Genet 125(5): 1069-1085.

19. Cortés A J, F López Hernández, D Osorio Rodriguez (2020) Predicting thermal adaptation by looking into populations genomic past. Front Genet 11: 564515 .

20. López Hernández F, A J Cortés (2019) Last Generation GenomeEnvironment Associations Reveal the Genetic Basis of Heat Tolerance in Common Bean (Phaseolus vulgaris L). Front Genet 10: 954.

21. Gulisano A, Sofia Alves, João Neves Martins, Luisa M Trindade (2019) Genetics and Breeding of Lupinus mutabilis: An Emerging Protein Crop. Front Plant Sci 10: 1385.

22. Cortés A J, F López Hernández (2021) Harnessing Crop Wild Diversity for Climate Change Adaptation. Genes 12.

23. Pironon S, James S. Borrell, Ian Ondo, Ruben Douglas, Charlotte Phillips, et al. (2020) Toward Unifying Global Hotspots of Wild and Domesticated Biodiversity. Plants 9(9): 1128.

24. Cortés AJ, Luz N Garzón, Jhon B Valencia, Santiago Madriñán (2018) On the Causes of Rapid Diversification in the Páramos: Isolation by Ecology and Genomic Divergence in Espeletia. Front Plant Sci 9: 1700.

25. Madriñán S, AJ Cortés, J E Richardson (2013) Páramo is the world's fastest evolving and coolest biodiversity hotspot. Front Genet 4: 192.

26. Reyes Herrera PH, Laura Muñoz-Baena, Valeria Velásquez-Zapata, Laura Patiño, Oscar A Delgado-Paz, et al. (2020) Inheritance of Rootstock Effects in Avocado (Persea americana Mill) cv Hass. Front Plant Sci 11: 555071

27. Valencia JB, Jeison M, Juan GL, Santiago M, Andres JC (2020) Climate Vulnerability Assessment of the Espeletia Complex on Páramo Sky Islands in the Northern Andes. Front Ecol Evol 8: 565708.

28. McCouch S, Gregory J Baute, James Bradeen, Paula Bramel, Peter $\mathrm{K}$ Bretting, et al. (2013) Agriculture: Feeding the future. Nature 499(7456): 23-24.

29. Spindel JE, SR McCouch (2016) When more is better: how data sharing would accelerate genomic selection of crop plants New Phytol 212: 814-826.

30. McCouch S, Zahra Katy Navabi, Michael Abberton, Noelle L Anglin, Rosa Lia Barbieri, et al. (2020) Mobilizing Crop Biodiversity. Mol PLant 13(10): 1341-1344. 